\title{
10
}

\section{Integrating Gender Perspective in Interpreter Training: A Fundamental Requirement in Contexts of Gender Violence}

\section{Carmen Toledano Buendía}

\section{Introduction}

Since the United Nations (UN) Declaration on the Elimination of Violence against Women, approved on 20 December 1993 by the General Assembly, the term "violence against women" is used to refer to:

any act of gender-based violence that results in, or is likely to result in, physical, sexual or psychological harm or suffering to women, including threats of such acts, coercion or arbitrary deprivation of liberty, whether occurring in public or in private life.

Gender violence is the extreme manifestation of the inequality and subjugation endured by women the world over and represents a clear violation of human rights. Its origins lie in a patriarchal culture that has perpetuated patterns of domination based on the supposed superiority

\section{Toledano Buendía $(\bowtie)$}

Department of English and German Philology, University of La Laguna, San Cristóbal de La Laguna - Tenerife, Spain e-mail: ctoledan@ull.es 
of men and the discrimination of women, which are justified by stereotypes or myths deeply rooted in society.

Gender violence is a universal problem. Around $20 \%$ of the female population is estimated to suffer violence of some kind. In Europe alone, the report Violence Against women: An EU-Wide Survey (2014) reveals that 13 million women experienced physical violence in the 12 months prior to the report, a figure equivalent to $7 \%$ of women aged between 18 and 74 years. Of women who are currently or have been in a relationship with a man, $22 \%$ have experienced physical and/or sexual violence.

Thanks to gradual progress in matters of social justice, many countries have introduced a set of measures, services and benefits for the prevention, assistance, protection and recovery of female victims of gender violence. However, for many immigrant women who endure all kinds of violence simply because of their gender, these resources may be restricted or even inaccessible because of limited knowledge or ignorance of the official language/s of the community in which they live. The particular overrepresentation of women from this collective in gender violence settings has been reported in various studies (Menjivar and Salcido 2002; Runner et al. 2009; Amnesty International 2007; Arnoso et al. 2012; Donoso and Venceslao 2013). In Spain, for example, 34.7\% of deaths resulting from domestic abuse in 2017 were immigrant women. This percentage highlights the overrepresentation of this group who account for just $9.5 \%$ of the female population of Spain.

Their administrative situation, family and social maladjustment, cultural values, ignorance of their rights and of existing services are some of the factors that hinder their chances of reporting the situation of violence in which they find themselves and, consequently, of escaping from it (see, for instance, Menjivar and Salcido 2002; Chocrón Giráldez 2011). Moreover, in many cases, linguistic barriers are for many immigrant women an additional obstacle that exacerbates their situation and their feelings of defencelessness and isolation, often becoming an insuperable impediment to their confronting, and fighting against, their situation of abuse. In these cases, linguistic assistance is vital, not only to provide immigrant women with these services, but also to ensure effective attention from all the professionals involved. As Huelgo et al. point 
out, "language access plays a central role in the ability of survivors to progress in their journeys to safety" (2006, p. 5).

Among these measures, the presence of professional interpreters at every stage of the process of attention and intervention plays a key role. Interpreters facilitate faithful and objective communication between interlocutors, so that victims can report their situation precisely and correctly, and can in turn be informed of their rights and obligations. Only if linguistic mediation is provided by professionals can immigrant victims of abuse feel supported in the same conditions as the rest of the population, and can the effective provision of this service be guaranteed, leading to the empowerment of women, a way out of the violent situation and the road to recovery (Lemon 2006; Toledano and Del Pozo 2015).

The need for public service interpreter preparation and specialization has been shown through various projects and studies, which have led to the development of resources, recommendations and training. ${ }^{1}$ Particularly noteworthy in Spain is the European project Speak Out for Support (SOS-VICS), the objective of which was to contribute to interpreter training and specialization in contexts of gender violence. ${ }^{2}$ In this chapter, we will attempt to justify the relevance of training for these professionals, placing special emphasis on the inclusion of gender perspective as a key skill for their capacity to interpret for female victims of gender violence and to ensure impartial, respectful and professional interpretation. Throughout this chapter, we will use some of the results and testimonies gathered in the research carried out as part of the SOS-VICS project. ${ }^{3}$

\section{Reasons for Interpreter Specialization in Gender Perspective}

At the Fourth World Conference on Women in Beijing, the UN defined violence against women as:

[...] a manifestation of the historically unequal power relations between men and women, which have led to domination over and discrimination against women by men and to the prevention of women's full advancement. (UN 1996, p. 49) 
The acquisition of gender awareness entails understanding violence as a consequence of sociocultural factors that affect male and female genders. By its very definition, this acquisition is considered an indispensable requirement for all the professionals who participate in assisting and protecting victims of this kind of violence. Every facet of this exercise in assistance necessitates not only understanding that violence against women does not derive from more or less irrational isolated or circumstantial personal reactions, but from a patriarchal regime and a sociocultural articulation of gender. But it also needs to militate against this status quo.

\subsection{Some Political Considerations}

For the past 50 years, many legal orders have protected women's rights to a violence-free life, urging governments to adopt the necessary measures to guarantee women's rights in accordance with the principle of non-discrimination, to develop policies and plans that help implement these rights, and to provide redress and reparation to those whose rights have been violated. Some examples include the Convention on the Elimination of All Forms of Discrimination against Women (CEDAW), approved in 1979 by the UN; the acclaimed Fourth World Conference on Women held in Beijing in 1995; and on a more recent European level, the Istanbul Convention (Council of Europe Convention on Preventing and Combating Violence Against Women and Domestic Violence), signed in 2011, and Directive 2012/29/EU of the European Parliament and the Council of 25 October 2012.

These documents pinpoint the special attention that must be paid to the specific needs of certain groups, which, for various reasons, such as age, religion or origin, may find themselves in a situation of greater vulnerability. This is the case for immigrant women who either do not speak the language of the community in which they live or they have a very limited knowledge of it. This is explicitly acknowledged, for example, in articles 3 (the right to understand and be understood) and 7 (the right to interpretation and translation) of the aforementioned directive, which contemplate the need for a free interpreting service in order to ensure effective communication. 
Moreover, the specialization and training in gender perspective of the agents involved in assisting gender violence victims is considered to be a key factor. The CEDAW, for example, commits States to contribute to eliminating the substrate of discrimination, that is the prejudices and discriminating stereotypes on the roles and attitudes of men and women (Naredo 2015, p. 41). And both article 61 of Directive 2012/29/EU of the European Parliament and the Council, and 1/2004 of the Istanbul Convention point to the need to promote specialization for the groups of professionals who intervene in the process of informing, assisting and protecting victims (Hertog 2015), ${ }^{4}$ including interpreters.

In the case of immigrant women who cannot speak the language, interpreters must provide the same guarantees as the other links in the chain: professional competence and no preconceptions. The performance of these interpreters may, or may not, be the key that opens the door to the effective exercise of the rights of some immigrant women. [Translated from Spanish] (Naredo 2015, p. 43) ${ }^{5}$

\subsection{Technical Reasons for Applying a Gender Perspective}

The political obligations or recommendations resulting from these documents are endorsed for technical reasons. The highly complex phenomenon of gender violence and the multiple needs raised by victims demand comprehensive attention, and the specialization of both the services and assistance resources, and the agents and operators who provide them. The team of professionals who assist victims must be aware of existing resources, legislation and measures available to women; they must act in a coordinated manner, following specific protocols in each area and from a gender perspective, in order to ensure efficient attention and to avoid the double victimization of women. Yet the efficiency of these resources in assisting women gender violence victims who do not speak or have a limited knowledge of the language of the community in which they live also entails overcoming the linguistic barrier in order to ensure correct communication between the parties, an aspect that is all too frequently overlooked (Lemon 2006; Vieria Morante 2015). 
The testimonies of the 12 survivors of gender violence interviewed in the SOS-VICS project reveal that ignorance of the language was as much an obstacle to understanding their rights and existing resources, as to explaining and expressing their situation of violence, and to understanding the process and consequences of it. As for the service providers, the professionals interviewed for the project cited the factors that hindered their work as follows: victims' ignorance of resources $(47.1 \%$ important and 29\% very important), distrust of the services (45.4\% important and $27.8 \%$ very important), cultural barriers (45.2\% important and $22.5 \%$ very important) and linguistic barriers (37.2\% important and 32.1\% very important). In all cases, the percentage of professionals interviewed who considered that the effectiveness of their work is in some way threatened by communicative problems was in excess of two thirds (Del Pozo et al. 2014a, p. 35). However, despite this professional's view, this project research reveals the absence, improvisation and lack of professionalism of the resources for linguistic assistance in Spain, even in areas where the law requires the presence of interpreters at all stages of criminal proceedings (Del Pozo and Toledano 2016; Vieria Morante 2015, p. 52). Consequently, as Lemon argues when referring to the USA, "the states or counties which do not provide this service are in fact denying victims of domestic violence access to the courts" (2006, p. 38). ${ }^{6}$

Evidently, if the lack of a communicative mediation service can be off-putting for defenceless victims, it is important to understand that improvising solutions to cover this deficiency can be even more serious. As one of the professionals interviewed in the SOS-VICS project, remarked:

I never worked with professional interpreters, just with persons close to victims. I have attended alleged foreign victims (Romanian, Moroccan) who did not make a complaint and it was impossible to talk to them about the matter since they were accompanied by the possible aggressor to the medical consultation. (Comment number 4 in Del Pozo et al. 2014a, p. 91)

The presence of family members-even children-friends, volunteers or untrained interpreters is the norm in many services and countries such Spain. Various research studies that analyze services rendered by 
untrained interpreters reveal deficiencies, hindrances and even failure to access public services on an equal basis, resulting in inadequate use of the institutional resources available to citizens (Abraham and Fiola 2006; Bischoff 2003; Bowen 2010; Cambridge 1999; Flores et al. 2003; Kelly and Bancroft 2007; Sánchez-Reyes and Martín 2005).

Issues such as lack of accuracy, editing of information, stance or lack of anonymity are common features of the interpreting carried out by untrained interpreters. In the case of gender violence, these features can bring fatal consequences. In terms of message accuracy, for example, Polzin argues that if it should be the norm in all interpreting processes, it is vital in the field of gender-based violence.

In order to get help, victims usually have to describe their experiences and share very intimate information when filling a report or during an initial intake meeting. This usually includes details about the physical or sexual assault that may feel shameful to discuss -even though the abuse is not the victim's fault- especially in front of a male interpreter. These details have important implications for a court case, and could affect the other types of services to which the victim is entitled. For example, substituting the word chest for breast in describing the assault, even if motivated by respect for the victim's modesty, conveys a very different meaning and could lead to a much different outcome. (2007, p. 23)

Likewise, untrained interpreters tend to summarize, edit interlocutors' interventions and enter into parallel conversations with the other parties (Knapp-Potthoff and Knapp 1987). This leads to the manipulation or alteration of the speakers' words, which is usually associated with the interpreter exceeding his/her role (Wandesjö 1998), thereby impeding the adoption of objective and neutral positions. This circumstance poses serious technical difficulties for intervention according to some of the agents in the surveys:

In most cases there were conversations with victims that went beyond the professional interview, which is unacceptable and this at times hampered the intervention. In most cases, they were from immigrant communities with unknown languages (African dialects, etc.) and we contacted 
interpreters from such linguistic communities and the interpreters happened to know the victim within her social environment, which is something I consider damaging to the intervention [...]. (Comment number 67 in Del Pozo et al. 2014a, p. 93)

For mediation in contexts of gender violence and child abuse, Huelgo et al. (2006, p. 6) pinpoint the crucial need for interpreters to be aware of the ethical and legal implications and demands of their work, and emphasize the importance of the neutrality of the intervention, confidentiality and absence of conflicts of interest that might interfere in the impartiality of the service provided.

It is vital to understand that the real profile of the phenomenon of gender violence demands not only that the resources used to combat it are complemented by linguistic assistance, but that this assistance is in itself a crossover resource that enables everything else to function. Furthermore, it is vital to understand that the services (legal, health, psychological, educational and care) provided to victims are not only essential but must, in one way or another, fully identify with communication. Not that there is any content to be communicated; the content itself forms the basis of this communication. Over and above the type of assistance offered to victims, dealing with the problem in more than just palliative terms requires a fundamentally communicative endeavour that can break down cultural barriers linked to the ontological conception of the world and human relations. These cultural barriers are increasingly accompanied by linguistic barriers that only reflect the surface of the problem.

In interventions with immigrant women, half the professionals interviewed consider that it is very important $(23.9 \%)$ or important $(23.2 \%)$ for interpreters to have received specific training in this area. Professionals from the legal and care sectors placed the most importance on this aspect (38.5\% very important and 24.8\% important) (Del Pozo et al. 2014a, p. 73).

This opinion appears to be shared by interpreters, as evidenced in the results of the Delphi survey undertaken as part of this project. Interpreters consider the lack and difficulties of accessing specialist training as an obstacle or hindrance to their work with gender violence 
victims (Del Pozo et al. 2014b, p. 19). Such training should encompass the mastery of various interpreting techniques, familiarity with and applicability of a professional or ethical code of conduct, knowledge of the fields of intervention and resources for coping with emotions and stress, and gender training (Abraham and Oda 2000; Toledano and Del Pozo 2015). Within the latter field, the interpreters participating in the Delphi survey agree on various topics as relevant to their specialization. Items relating to gender violence are mentioned, such as manifestations of violence against women/gender-based violence; the concept of violence against women/gender violence or the cycle of violence received a high level of consensus. Other items relating to gender equality such as the sex/gender system; the private, public and domestic space; the mainstreaming of the gender perspective; and stereotypes and gender roles or the gender perspective received a moderate level of consensus (Del Pozo et al. 2014b, p. 15).

\subsection{Ethical Reasons. Technical Neutrality vs. Moral Neutrality}

Inclusion of gender perspective in training professionals and interpreters is not merely a political and technical obligation, but also a moral one. Gender violence, by nature, does not simply derive from the effective and specific exploitation of unequal power between individuals; it derives from the stable cultural representation of a hierarchical relationship between genders.

The work of the interpreter is a vital tool for guaranteeing the rights of persons who most need them. However, we must not think of it solely as a tool for reinstating victims' rights, but as a vital resource for reverting their condition through empowerment. In order for this empowerment to be effective, the communication task cannot be mistaken for a simple, objective translation of the statements; it must be a clear discernment of the fact that this 'objectivity' is based on a representation of the corresponding reality.

Communicative mediation with gender violence victims requires a stance both against violence and the order of things that sustains 
violence. An order of things that can be shared culturally in a specific community and is rooted in its language. Consequently, faced with the almost unanimously defended neutrality stipulated in professional codes of ethics that govern interpreters' practice, we believe it appropriate to distinguish, as Romero (2010) does in relation to psychosocial intervention, between technical and moral neutrality. Although interpreting demands technical neutrality, interventions with gender violence victims do not admit moral neutrality:

There can be no neutrality before a gender violence victim: it is important to know that one person metes out violence and another suffers from it. The technical neutrality of the therapist is not the same as moral neutrality. Working with victims demands a moral attitude of commitment. Showing solidarity with the victim is necessary, though this does not imply a simplistic idea that she can do no wrong or be mistaken, but rather "requires an understanding of the fundamental injustice of traumatic experience and the need to return some sense of justice to the victim" (Herman 2004, p. 214). The professional's clear stance against violence can contribute to this. [Translated from Spanish] (Romero 2010, p. 193) ${ }^{7}$

For this commitment to be endorsed, it is vital that interpreters understand their task not as a temporary outsourced job to provide a service for the true service providers, and therefore as merely instrumental, but rather as one that fulfils a core mission directly for the service of victims and for the eradication of the state of things that places those victims in precisely that situation.

The professional code of conduct has an ethical basis, since it is associated with correct procedure. This procedure entails decision-making in accordance with guidelines on what is correct or fair, based on norms and values - not only the professional ones-that individuals have internalized throughout their lives according to their training and experiences. Acquiring the capacity to perceive, question and reflect on these values is a fundamental phase in the training of professionals in intervention in matters of gender violence (Nogueiras García 2004, p. 50). A capacity that, far from resulting in invisibility or weakness, brings about self-awareness. 
It is vital to understand that the reparation pursued in the intervention with female gender violence victims often involves internalizing —also on the part of the victim —ontological assumptions that may sometimes be equally traumatic. Ensuring the skills required to contribute to this communicative objective by making technical neutrality compatible with the clear stance of the professional that an objective interpretation demands (that is, implied in the communicative context and coherent with the order of things being established) is impossible without specialized training, which, in the case of interpreters, goes way beyond a knowledge of working languages, mastery of interpreting techniques or thematic competence. The intervention with gender violence victims requires the acquisition of gender perspective and gender training.

Social myths and stereotypes associated with the way women are regarded and abused influence people's attitudes largely because they are firmly rooted in language. It is therefore important to learn to identify them, not for the purposes of understanding women (specific victims of violence) but rather to understand ourselves in our mission to comprehend the representation of these women in the discourse and to mobilize our capacity to intervene in situations of mediation that are conflicting on levels that always extend beyond the personal sphere.

Interpreting with gender violence victims and survivors occurs in an individual case that always has a social dimension, since "this crime is held on cultural and social values and myths that justify/excuse male violent behaviours against women" (Walker 1979, p. 19), and according to Angelelli:

During the encounters which occur within the institutions, as interlocutors bring their own set of beliefs, attitudes, and deeply held views on interpersonal factors, such as gender, race ethnicity, and socioeconomic status, all of these get enacted. (2008, p. 149)

The lack of agency and invisibility as basic principles of the model of interpreter performance can only be approached from the ingenuousness of conceiving interpretation mediation as a merely instrumental and invisible exercise. Technical neutrality can only be ensured from involved interpretation and the exposure of communicative conflicts, 
and the agency involved in the willingness to resolve them. A neutrality that requires an attitudinal capacity on the part of the interpreter in order to guarantee performance from a gender perspective; that is, the very questioning of the personal stance of the interpreter.

Working in the field of violence against women requires us to become aware, on a personal and professional level, of our own assumption of sexist stereotypes and prejudices, the values, attitudes and education that we have internalized, as well as many behaviours and expectations depending on gender assignation and identity. [Translated from Spanish] (Nogueiras García 2004, p. 50) ${ }^{8}$

To ignore the position of women and the gender-based factors on which that position is based (often operant in interlocutors) when interpreting for female gender violence victims can induce us to not only normalize, justify or diminish the importance of that violence, but to lose sight of the objectives of the work, by seeking reconciliation solutions as a result of a personal interpretation of the conflict that will only serve to re-victimize the woman.

Interviewee: Well, it's true. The interpreter who was at the... when there was a quick trial, three days after I reported my case, the interpreter was a Moroccan boy and of course, he didn't need to explain anything to me because I understood perfectly, but when he said that-well!that I should go back to him, that I should try and sort things out, for my children...

Sociologist: The interpreter?

Interviewee: The interpreter, the Moroccan boy. I was amazed. I was shocked. Really! And I just stood there and I said...

(Interviewee number 8. Moroccan woman) [Interview transcript. Translated from Spanish $]^{9}$

This is just one of various examples (transcriptions of statements) in which the interpreter infringes his commitment to technical neutrality and, from a background of cultural values that normalizes violence, encourages mediation and reconciliation-an impossible task. Yet the 
example clearly shows that the interpreter cannot be considered a channel between a transmitter and a receiver, but rather another voice with privileged access to certain parts that we can only theoretically regard as interlocutory, since only in a few cases do they communicate with each other. Correcting these surprisingly common divergences, which can easily derail the efforts of a large team of specialists in just a couple of utterances, does not depend on linking interpreters' ethical commitments to controlling their overperformance but to the need for a process of personal questioning and an exercise of (personal and professional) awareness.

This difficult task of giving a voice to those who have none, without speaking for them, calls for gender perspective as well as learning to recognize and manage affective reactions resulting from the encounter with the victim. These reactions are the outcome of various factors arising from both the perception of the episode and the generic representation of abused women, and the order of things in which the abuse takes place. Localized, prejudiced reactions that we cannot prevent from affecting us when empathizing, communicating and interpreting (Millán 2004, pp. 155-157). Objectivity can only derive from the representation and visibility of (the agency of) that subjectivity, which has nothing to do with our personal interpretation, but rather with the social context that determines that our performance can be considered an interpretation. Training is not aimed at learning not to feel but at learning to instrumentalize what is felt for the benefit of the intervention.

The set of attitudes, feelings and thoughts experienced by therapists in relation to patients is known in psychology as countertransferential attitudes (Romero 2010, p. 194). Countertransference, which occurs in the inner world of the professional when meeting an abused patient, provokes and arouses feelings that can, according to Romero, lead to positions ranging between blaming the victim and overidentification. Victim blaming can be seen as a form of defence against the anxiety, fear or shame we feel when facing the problem of the other. This feeling of rejection, arising from an eventual cultural identification, often leads us to regard victims as rentiers or recipients of secondary benefits (Velázquez 2003 as cited in Romero 2010, p. 194). Another more 
common and subtle form of rejection is lack of commitment or neutrality, a distancing and lack of empathy that causes the re-victimization of women.

Conversely, we can swing to the opposite extreme, which results in an intense involvement that can be accentuated for interpreters when faced with the responsibility of being the only facilitator of communication. This attitude, which entails interpreters assuming functions that do not correspond to them, may raise mistaken expectations in victims about the specific possibilities of their case, thereby generating new relations of dependency. To avoid paternalistic or condescending attitudes, which are not exclusive to interpreters and which ultimately lock women into a dependent role, it is vital to interpret their vulnerability as discrimination, which does not require protection but fairness, equal opportunities and expectations (López Méndez 2007, p. 35).

Interpreters' frequent ignorance or denial of their countertransferential attitudes underpins the position of victims in either of these two common expressions, hindering their development and personal growth in the process of making emancipated and autonomous decisions. In other words, they block women's empowerment and agency over their own lives, which is the end target of all interventions in gender violence.

\section{Conclusion}

The complex process of acquiring awareness and agency that women must negotiate in order to report the violence to which they are being subjected is personal and unique. Organizations can facilitate or contribute to this process by providing information, guidance, support, means, accompaniment and so forth. However, the ultimate decision to face the problem is personal and non-transferable. Taking the decision on behalf of victims always results in failure. It is therefore not a question of speaking for victims but of giving them a voice, a subtle moral imperative in which all expectations of technical neutrality must be framed. Such neutrality certainly does not derive from a distanced attitude, but entails committed involvement in a training process that begins with the deconstruction of interpreters' own technical capacity. 
This responsibility, linked to self-awareness, requires the parallel acknowledgement of interpreters' role as key agents in the intervention process, from their ethical stance against violence and from a gender perspective.

\section{Notes}

1. To mention just a few examples, in Canada, a pilot project involving a group of specialist interpreters was created to provide mediation in the domestic violence court in Ontario and at a service about domestic violence at the Women's College Hospital in Toronto (Abraham and Oda 2000). In the USA, we find resources such as those of the National Center for States Courts (Access to Justice: Limited English Proficiency (LEP) and Access to Protection Orders), or the Department of Justice Office on Violence Against Women (Resource Guide for Advocates \& Attorneys on Interpretation Services for Domestic Violence Victims); also in the USA, the training programme and resources offered by the Voice of Love (Healing Voices: Interpreting for Survivors of Torture, War Trauma and Sexual Violence http://www.volinterpreting.org/); in Australia materials published by the Community Relations Commission for a multicultural New South Wales (Using Interpreters in Domestic Violence and Sexual Assault Matters) and the project "Breaking through the language barrier: Empowering refugee and immigrant women to combat domestic and family violence through cultural and language training", led by Dr. Sandra Hale, with government funding through the NSW Department of Premier and Cabinet, Domestic and Family Violence Grant scheme. In Ireland, the Dublin Rape Crises Center created a manual for interpreters in cases of gender violence, Interpreting in Situations of Sexual Violence and Other Trauma (2008) (http://www.drcc.ie/wp-content/ uploads/2011/03/RCC_Interpreting.pdf). See also Costa (2015), Lemon (2006), and Wallace (2015) for the importance of interpreter training in US Civil courts for victims of domestic violence. And finally, practical recommendations aimed at professional interpreters and published in the bulletins of professional associations such as Polzin (2007) and Huelgo et al. (2006).

2. Speak Out for Support (SOS-VICS) (JUST/2011/JPEN/2912) is a European project co-funded by the Criminal Justice Programme of the 
European Union. All results can be accessed through the project web site: http://cuautla.uvigo.es/sos-vics/.

3. The following research studies were performed within the SOS-VICS project framework: a questionnaire survey of 586 agents with experience in assisting foreign female gender violence victims (social, health, police and court fields); a Delphi survey of 27 interpreters who had experience in assisting foreign female gender violence victims, and semi-structured interviews with 12 victims and 12 agents. For complete reports see Del Pozo et al. (2014a, b). For confidentiality purposes only, project partners have access to the transcripts of the interviews with agents and victims.

4. For an exhaustive review of this directive, see Hertog (2015). For an overview of European and international human rights instruments that set down the obligation of states to provide specialised interpreting to victims of gender violence, see Naredo (2015). Specific to translation and interpreting and the need for professionalization and specialisation of interpreters that intervene during the criminal process is Directive 2010/64/UE of the European Parliament and of the Council of 20 October 2010 on the right to interpretation and translation in criminal proceedings (Blasco and Del Pozo Triviño 2015).

5. En el caso de mujeres extranjeras que desconocen el idioma, es preciso aplicar a los y las intérpretes las mismas garantías que al resto de eslabones de la cadena, competencia profesional y ausencia de prejuicios. De ello puede depender que su actuación constituya, o no, la llave que abre la puerta al ejercicio efectivo de los derechos paro parte de las mujeres extranjeras.

6. Lemon's research focuses on the need for free professional interpreters in civil domestic violence cases in the United States and the importance of their training.

7. No existe la neutralidad ante una víctima de violencia: hay que saber que hay quien ejerce violencia y hay quien la padece. La neutralidad técnica del terapeuta no es lo mismo que la neutralidad moral. Trabajar con personas victimizadas exige que se tenga una actitud moral de compromiso. Es necesario tomar una postura de solidaridad con la víctima, lo que no supone una idea simplista de que ésta no pueda hacer nada malo o equivocado sino que "exige el entendimiento de la injusticia esencial de la experiencia traumática y la necesidad de devolver a la víctima alguna sensación de justicia” y a esto contribuye el claro posicionamiento del profesional contra la violencia. 
8. Trabajar en el área de la violencia contras las mujeres nos exige tomar conciencia, tanto a nivel personal como profesional, de nuestra propia asunción de estereotipos y prejuicios sexistas, los valores, actitudes y educación que hemos interiorizado, muchos comportamientos y expectativas en función de la asignación e identidad de género.

9. E: es que es verdad, el intérprete que estuvo en el... cuando hubo el juicio rápido a los tres días de poner yo la denuncia, el intérprete era el chico marroquí y claro, a mí no me tuvo que explicar nada porque lo entendía perfectamente pero un momento que me dijera, me dijo él a mí, que vamos! que volviera con él, que intentara arreglar las cosas, por las niñas...

S: ¿el intérprete?

E:el intérprete, el chico marroquí, me parecía increíble, me pareció superfuerte, jes verdad! y yo me quedé ahí y digo...

\section{References}

Abraham, D., and M.A. Fiola. 2006. Making the Case for Community Interpreting in Health Care: From Needs Assessment to Risk Management. In Taking Stock: Research and Methodology in Community Interpreting. Linguistica Antverpiensia, ed. E. Hertog and B. Van der Veer, vol. 5, 189-202.

Abraham, D., and M. Oda. 2000. The Cultural/Community Interpreter in the Domestic Violence Court: A Pilot Project. In The Critical Link 2; Interpreters in the Community, ed. D. Abraham, R. Roberts, S. Carr, A. Dufour, and J. Benjamins, 165-189. Amsterdam and Philadelphia: John Benjamins.

Amnesty International. 2007. Más riesgos y menos protección. Mujeres inmigrantes en España frente a la violencia de género. Retrieved from https://www. es.amnesty.org/uploads/media/Informe_Mas_riesgos_y_menos_proteccion_231107.pdf.

Angelelli, C. 2008. The Role of the Interpreter in the Healthcare Setting. In Crossing Borders in Community Interpreting: Definitions and Dilemmas, ed. C. Valero-Garcés and A. Martin, 147-163. Amsterdam and Philadelphia: John Benjamins.

Arnoso, M., A. Arnoso, M. Mazkiaran, and A. Irazu. 2012. Mujer inmigrante y violencia de género: factores de vulnerabilidad y protección. Migraciones 
32: 169-200. Retrieved from https://revistas.upcomillas.es/index.php/ revistamigraciones/article/viewFile/912/772.

Bischoff, A. 2003. Caring for Migrant and Minority Patients in European Hospitals. A Review of Effective Interventions. Neuchâtel: Swiss Forum for Migration and Population Studies. http://www.mfh-eu.net/public/files/ mfh_literature_review.pdf.

Blasco, M.J., and M. Del Pozo Triviño (eds.). 2015. Legal Interpreting at a Turning Point/La interpretación en el ámbito judicial en un momento de cambio. MonTI 7. Retrieved from http://rua.ua.es/dspace/handle/10045/52536. Bowen, S. 2010. From 'Multicultural Health' to 'Knowledge Translation'. Rethinking Strategies to Promote Language Access Within a Risk Management Framework. Jostrans 14: 145-164. Retrieved from http:// www.jostrans.org/issue14/art_bowen.pdf.

Cambridge, J. 1999. Information Loss in Bilingual Medical Interviews Through an Untrained Interpreter. Dialogue Interpreting. The Translator Studies in Intercultural Communication 5 (2): 201-219.

Chocrón Giráldez, A.M. 2011. Víctimas extranjeras de violencia de género: derechos y medidas de protección. In F.J. García Castaño \& N. Kressova (Coords.), Actas del I Congreso Internacional sobre Migraciones en Andalucía (pp. 2159-2167). Granada: Universidad de Granada.

Costa, B. 2015. Working as a Team: The Importance of Training and Clinical Supervision of Interpreters and Practitioners for Best Practice in Gender Violence Contexts. In Construir puentes de comunicación en el ámbito de la violencia de género/Building Communication Bridges in Gender Violence, ed. M. Del Pozo Triviño, C. Toledano Buendía, D. Casado Neira, and D. Fernandes, 61-71. Granada: Comares.

Council of Europe. 2011. Convention on Preventing and Combating Violence Against Women and Domestic Violence, 11th May 2011. Brussels.

Del Pozo Triviño, M., and C. Toledano Buendía. 2016. Training Interpreters to Work with Foreign Gender Violence Victims in Police and Court Settings. In Language and Law Linguagem e Direito, guest editors M. Coulthard and S. Hale, 3-2, 192-203.

Del Pozo Trivińo, M., A. Vaamonde, D. Casado-Neira, S. Pérez Freire, A. Vaamonde, M.D. Fernandes, and R. Guinarte. 2014a. Comunicación entre profesionales de la atención en violencia de género y víctimas/supervivientes que no hablan el idioma. Informe sobre la encuesta a agents del proyecto Speak Out for Support (SOS-VICS)/Communication Between Professionals Providing Attention and Gender Violence Victims/Survivors Who Do Not Speak the Language. A Report on the Survey Carried Out on 
Agents During the Speak Out for Support (SOS-VICS) Project. Servicio de Publicaciones de la Universidad de Vigo. Retrieved from http://sosvicsweb. webs.uvigo.es/blogs/files/report-on-the-survey-carried-out-on-agentsduring-the-speak-out-for-support-sos-vics-project.pdf.

. 2014b. Formación especializada en interpretación para víctimas/supervivientes de violencia de género. Informe sobre la encuesta DELPHI a intérpretes del proyecto Speak Out for Support (SOS-VICS)/Specialised Training for Interpreters Working with Gender Violence Victims/Survivors. A Report on the Delphi Survey Carried Out on Interpreters During the Speak Out for Support (SOS-VICS) Project. Servicio de Publicaciones de la Universidad de Vigo. Retrieved from http://sosvicsweb.webs.uvigo.es/blogs/files/report-on-thedelphi-survey-carried-out-on-interpreters.pdf.

Donoso, T., and M. Venceslao. 2013. Apoyo psicosocial en mujeres migradas victimas de violencia de género. Fundación Obra Social La Caixa.

EU. Directive 2010/64/EU of the European Parliament and of the Council on the Right to Interpretation and Translation in Criminal Proceedings. Retrieved from http://eurlex.europa.eu/LexUriServ/LexUriServ.do?uri=OJ:L:2010:28 0:0001:0007:en:PDF.

EU. Directive 2012/29/EU of the European Parliament and of the Council of 25 October 2012 Establishing Minimum Standards on the Rights, Support and Protection of Victims of Crime, and Replacing Council Framework Decision 2001/220/JHA. Retrieved from http://eur-lex.europa.eu/LexUriServ/ LexUriServ.do?uri=OJ:L:2012:315:0057:0073:EN:PDF.

Flores, G., B. Laws, S. Mayo, B. Zuckerman, M. Abreu, L. Medina, and E. Hardt. 2003. Errors in Medical Interpretation and Their Potential Clinical Consequences in Pediatric Encounters. Pediatrics 111 (1): 6-14.

FRA [European Union Agency for Fundamental Rights]. 2014. Violence Against Women: An EU-Wide Survey: MAIN Results Report. Retrieved from http://fra.europa.eu/sites/default/files/fra-2014-vaw-survey-mainresults-apr14_en.pdf.

Hertog, E. 2015. The Right of Victims to Understand and Be Understood: The SOS-VICS Project Against Its EU Background. In Construir puentes de comunicación en el ámbito de la violencia de género/Building communication bridges in gender violence, ed. M. Del Pozo, C. Toledano Buendía, D. Casado-Neira, and D. Fernandes, 19-35. Granada: Comares.

Huelgo, V., S. Kaushat, P. Shah, and C. Shugrue dos Santos. 2006. The Voice of Justice: Interpreting Domestic Violence Cases. Proteus. The Newsletter of the National Association of Judiciary Interpreters and Translators XV (2): 4-6. 
Kelly, N., and M. Bancroft. 2007. The Critical Role of Health Care Interpreting: Views from the Literature, Promising Practices and Lessons Learned in the United States. In Culturally Appropriate Health Care by Culturally Competent Health Professionals. International Workshop Report, ed. Len Epstein, 85-100. Caesarea, Israel: The Israel National Institute for Health Policy and Health Services Research.

Knapp-Potthoff, A., and K. Knapp. 1987. The Man (or Woman) in the Middle: Discoursal Aspects of Non-professional Interpreting. In Analysing Intercultural Communication, ed. K. Knapp and W. Enninger, 181-211. The Hague: Mouton.

Lemon, N.K. 2006. Access to Justice: Can Domestic Violence Courts Better Address the Need of Non-English Speaking Victims of Domestic Violence. Berkeley Journal of Gender, Law \& Justice 21 (1): 38-58. Retrieved from http://scholarship.law.berkeley.edu/bglj/vol21/iss1/3.

López Méndez, Irene. 2007. Enfoque de género en la intervención social. Cruz Roja. Menjivar, Cecilia, and Olivia Salcido. 2002. Immigrant Women and Domestic Violence: Common Experiences in Different Countries. Gender and Society 16 (6): 898-920. Retrieved from http://www.jstor.org/stable/3081940.

Millán Susinos, R. 2004. El trabajo social con mujeres maltratadas. Intervención individual. In C. Ruíz-Jarabo Quemada \& P. Blanco Prieto (directs.), La violencia contra las mujeres. Prevención y detección (pp. 47-54). Madrid: Ediciones Díaz de Santos.

Naredo, M. 2015. La interpretación especializada en violencia de género, una obligación de derechos humanos. In Construir puentes de comunicación en el ámbito de la violencia de género/Building Communication Bridges in Gender Violence, ed. M. Del Pozo Triviño, C. Toledano Buendía, D. Casado Neira, and D. Fernandes, 37-46. Granada: Comares.

Nogueiras García, B. 2004. La violencia en la pareja. In Consuleo Ruíz-Jarabo Quemada \& Pilar Blanco Prieto (direct.) La violencia contra las mujeres. Prevención y detección (pp. 39-55). Madrid: Ediciones Díaz de Santos.

Polzin, J.J. 2007. Interpreting in Domestic Violence Service Settings. The ATA Chronicle, 22-26.

Romero, I. 2010. Intervención en Violencia de Género: Consideraciones en torno al Tratamiento. Intervención Psicosocial 19 (2): 191-199. Retrieved from http://scielo.isciii.es/pdf/inter/v19n2/v19n2a10.pdf.

Sánchez-Reyes, S., and M. Martín Casado. 2005. Intérpretes profesionales e intérpretes 'ad hoc' en un entorno sanitario. In Traducción como mediación entre lenguas y culturas, ed. C. Valero, 139-146. Alcalá de Henares: Universidad de Alcalá Servicio de Publicaciones. 
Toledano Buendía, C., and M. Del Pozo Triviño (eds.). 2015. Interpretación en contextos de violencia de género. Valencia: Tirant Lo Blanch. Retrieved from http://cuautla.uvigo.es/sos-vics/blogs/files/manual-para-interpretes-sosvics.pdf. United Nations. 1993. Declaration on the Elimination of Violence Against Women. Retrieved from http://www.un.org/documents/ga/res/48/a48r104. htm.

1996. Report of the Fourth World Conference on Women Beijing, 4-15 September 1995. Retrieved from http://www.un.org/womenwatch/daw/beijing/pdf/Beijing\%20full\%20report\%20E.pdf.

United Nations Women. 1979. The Convention on the Elimination of All Forms of Discrimination against Women (CEDAW). Retrieved from http://www. un.org/womenwatch/daw/cedaw/.

Velázquez, S. 2003. Violencias cotidianas, violencia de género. Buenos Aires: Paidós.

Vieria Morante, F.J. 2015. El derecho a la asistencia lingüística de las víctimas de violencia de género en los ámbitos policial y judicial: situación actual y retos. In Construir puentes de comunicación en el ámbito de la violencia de genero/Building Communication Bridges in Gender Violence, ed. M. Del Pozo Triviño, C. Toledano Buendía, D. Casado Neira, and D. Fernandes, 47-54. Granada: Comares.

Walker, L.E. 1979. The Battered Woman. New York: Harper \& Row.

Wallace, M. 2015. Access and Protection: Civil Court Remedies for Victims of Domestic Violence and the Current State of Free Language Mediation in US Courts. In Construir puentes de comunicación en el ámbito de la violencia de genero/Building Communication Bridges in Gender Violence, ed. M. Del Pozo Triviño, C. Toledano Buendía, D. Casado Neira, and D. Fernandes, 73-81. Granada: Comares.

Wandesjö, J. 1998. Interpreting as Interaction. London: Longman.

Yoshihama, M., M. Runner, and S. Novick (eds.). 2009. Intimate Partner Violence in Immigrant and Refugee Communities: Challenges, Promising Practices and Recommendations. Robert Wood Johnson Foundation. Retrieved from https://www.futureswithoutviolence.org/userfiles/file/Immigrant Women/IPV_Report_March_2009.pdf. 